The State in Modern Society 
Also by Roger King

Capital and Politics

The Middle Class (with J. Raynor)

Respectable Rebels (with N. Nugent)

The British Right (with N. Nugent) 


\title{
The State in Modern Society
}

\section{New Directions in Political Sociology}

\author{
Roger King \\ with Chapter 8 by Graham Gibbs
}


(C) Roger King 1986

Chapter $8 \odot$ Graham Gibbs 1986

All rights reserved. No reproduction, copy or transmission of this publication may be made without written permission.

No paragraph of this publication may be reproduced, copied or transmitted save with written permission or in accordance with the provisions of the Copyright, Designs and Patents Act 1988, or under the terms of any licence permitting limited copying issued by the Copyright Licensing Agency, 90 Tottenham Court Road, London W1P 9HE.

Any person who does any unauthorised act in relation to this publication may be liable to criminal prosecution and civil claims for damages.

First published 1986 by

MACMILLAN PRESS LTD

Houndmills, Basingstoke, Hampshire RG21 2XS

and London

Companies and representatives

throughout the world

ISBN 978-0-333-36607-3

DOI 10.1007/978-1-349-18269-5

A catalogue record for this book is available from the British Library.

$\begin{array}{llllllll}10 & 9 & 8 & 7 & 6 & 5 & 4 & 3\end{array}$

$\begin{array}{llllllll}07 & 06 & 05 & 04 & 03 & 02 & 01 & 00\end{array}$ 
For Sue, Helen, Tim and Vera 


\section{Contents}

Acknowledgements $\quad$ x

Introduction $\quad \mathrm{xi}$

1 Behaviouralism and the Sociology of Democracy 1

Introduction 1

Political behaviour and American political sociology 5

The sociology of democracy: Almond and Verba, Lipset 8

Critiques of behaviouralist accounts of democracy $\quad 16$

Values and the sociology of democracy 18

Electoral alignment and de-alignment in Britain 21

Conclusions $\quad 29$

2 The Development of the Modern Nation-State 31

Introduction 31

Feudalism, patrimonialism and the Standestaat $\quad 32$

The Standestaat $\quad 38$

The Absolute State $\quad 39$

The development of capitalism and parliamentarism $\quad 43$

The French state and social revolution $\quad 47$

The liberal constitutional state $\quad 51$

Conclusion $\quad 57$

3 Interpretations of the Development of the Modern State 59

Introduction $\quad 59$

Durkheim: the state and the division of labour $\quad 60$

Marx, Engels and Lenin $\quad 61$

Leninism 66

Weber: bureaucracy and the state $\quad 70$

Recent Marxist theories of the state 73 
viii Contents

Miliband and Poulantzas $\quad 75$

Crises and contradictions: Offe and Habermas $\quad 80$

Conclusion: 'post-Marxism' $\quad 83$

4 Liberalism, Collectivism and State Socialism 8

Introduction $\quad 86$

Liberalism and collectivism $\quad 89$

The emergence and development of collectivism 96

Fascism 104

State socialism 105

Conclusion: post-1945 111

5 Corporatism 115

Pluralism and liberal democracy $\quad 115$

The emergence of corporatism 118

Interpretations of corporatism $\quad 120$

Market, bureaucratic and corporatist forms of decision making 123

Corporatism as interest intermediation $\quad 127$

The dimensions of corporatism 131

Who benefits? 134

Local corporatism 136

Corporatism and welfare 138

$\begin{array}{ll}\text { Conclusion } & 139\end{array}$

6 Power 141

Introduction 141

Three conceptions of power 143

Decisional or pluralist accounts of power 144

Non-decisionalism or the two faces of power 147

Radical approaches to power 151

The case of business power $\quad 157$

$\begin{array}{ll}\text { Conclusion } & 161\end{array}$

7 Urban Politics 162

Introduction 162

Central and local functions and relations $\quad 164$

Urban power 168 
Urban managers $\quad 174$

Collective consumption and urban politics 176

Local state, dual state and consumption sectors $\quad 180$

Local corporatism and structure $\quad 185$

Conclusion: public sector unionism and professionalism 188

8 The State in an International Context (by Graham Gibbs) 192

Introduction 192

Modernisation and modernisation theory 193

Political development 197

Criticisms of modernisation theory $\quad 200$

Imperialism 204

Imperialism today? 208

Underdevelopment and world systems $\quad 212$

Criticisms of world systems approaches 217

Relative autonomy in the world economy 222

State and international economic system 223

Transnational corporations and the state 226

The authoritarian state $\quad 232$

Conclusion 238

9 Postscript: The State and the New Cold War 240

Imperialism and the superpowers $\quad 240$

The new cold war $\quad 247$

Bibliography 255

$\begin{array}{ll}\text { Index } & 267\end{array}$ 


\section{Acknowledgements}

I am very grateful to colleagues over many years who have assisted me in my thinking about political sociology, particularly David Jary who introduced me to the subject and who has continued to be a source of illumination ever since. Steven Kennedy at Macmillan will also have to share some of the responsibility for what follows as he persuaded me that the book could and should be written, although other commitments appeared too daunting for me to even contemplate the effort of producing a political sociology text. However, I am extremely grateful to Graham Gibbs for his chapter on the state in an international context, not only for the valuable dimension that this brings to the book, but also for the relief that his agreement to do it afforded me at the time.

Finally, I must thank my wife, Sue, for helping to provide the conditions without which this book could not have been written.

\section{Humberside College of Higher Education Roger King}

The author and publishers wish to thank the following who have kindly given permission for the use of copyright material: Cambridge University Press for extracts from 'Urban Politics and Markets' by R. P. King from British Journal of Political Science, vol. 15; Longman Group Ltd. for extracts from The Middle Class by R. P. King and J. Raynor; Plenum Publishing Corporation for 'Sociological Accounts of Power and Political Processes' from Behavioural Decision Making, ed. G. Wright; The Politics Society for extract from 'Updating: Political Sociology' from Teaching Politics, vol. 11, no. 1, Jan. 1982. Every effort has been made to trace all the copyright-holders, but if any have been inadvertently overlooked the publishers will be pleased to make the necessary arrangement at the first opportunity. 


\section{Introduction}

The last two decades in the social sciences have been characterised by change and rapid developments, and this is exemplified by political sociology. As a well-established area of study, with a recognised set of issues and approaches (democracy/nondemocracy), it had in the early 1960s an air of orthodoxy, even complacency. Yet today no one is sure what political sociology is, or even whether it still exists. Earlier assumptions have been challenged, overturned and have occasionally re-emerged, often in a different guise. People who call themselves political sociologists, in contrast to their predecessors of twenty years or more ago, are more interested in state and economy than socialisation and culture, and the approaches employed are generally more critical and diverse.

Many political sociologists see this increased fragmentation as a sign of growth and openness, reflecting the liberalism and plurality of its major topic-democracy. It is preferred to what they regard as the palsied state of 'cold-war' political sociology that spanned the Atlantic in the 1950s and 1960s. Others, however, prefer a science with a firmer set of verities, with knowledge accumulating on the basis of a uniform and dominant model. Whichever, political sociology is very different now from what it was twenty years ago.

However, it would be easy, and mistaken to overlook the continuities with an earlier period in contemporary political sociology. The current concern with the state, for example, not only resonates with the dilemmas that also confronted the classical European sociologists at the turn of the century, but in its increased 


\section{xii Introduction}

rapprochement between Marxism and Weberianism, also echoes the 'grand' social science of an earlier period. It perhaps brackets the post-1945 'orthodoxy', with its unconcern with the state and focus instead on politics and power, as the aberration rather than its more radical contemporary counterpart.

This book seeks to take stock of political sociology by examining the continuities as well as the breaks with an older political sociology. It starts with an examination in Chapter 1 of the traditional political sociology that has dominated in both the United States and Britain in recent years. Rooted in behaviouralism it is characterised largely by an unconcern with the state and with generating a pragmatic, 'realistic' response to participatory democratic theory. American behaviouralism was an especially significant force in the United States in the inter-war years and contrasted with the more speculative or 'macro' concerns of European political sociology by focusing on individuals, power and values. There was a concern with detailed and methodologically rigorous enquiry into the social psychological aspects of politics and the ways in which 'non-political' institutions such as the family and the media acted to create political attitudes. The focus was on the 'ordinary man' or the behaviour of the 'non-élite' rather than the élite, and explanations of voting patterns or other forms of political participation rested on the attitudes generated in wider socialisation and cultural processes. Power was regarded as voluntaristic and divorced from the state or class power and was conceived individualistically or atomistically as the ability of actors to control others in social relationships.

However, the 'sociology of democracy', which became the orthodoxy on both sides of the Atlantic in the post-1945 decades, was founded on the link between American behaviouralism and European democratic theory. It sought to revise classical assumptions of participatory democracy, the claimed benefits to both individuals and the political system gained through extensive involvement in decision making, by noting the relative disinterest in politics by most individuals found in election and other studies of political behaviour. Rather, democracy was best exemplified by stability and consensual values. The agenda for political sociology became characterised by two assumptions. First, that the liberal regimes in most of the western industrial nations were as democratic as one could reasonably expect and that the issue was to identify 
how such regimes could be stabilised and their example furthered elsewhere. Second, that social processes largely determined political arrangements, and that the answer to the issue of stabilising liberal democracy lay in establishing the social causes or requisites of democracy.

In Chapter 1 we examine recent critiques of the role of values in traditional political sociology, focusing especially on Britain as the alleged exemplar of a stable democracy. We also consider recent election studies which display a more critical approach to behaviouralism and a greater recognition of structured inequalities, not least by the state, as the basis for opposed political outlooks. However, the main theme of the book is to suggest that a major dissatisfaction with orthodox political sociology has been its neglect of the state. New approaches in political sociology have recognised the need to return to earlier concerns with the state as found in both Marxism and Weberianism. In contrast to classical interpretations, however, contemporary political sociology is characterised by a more sophisticated account of the relationship between state and economy than found in early Marxism, and recognises the state as a structured source of inequality and power, and not simply a reflection. Moreover, there is a less satisfied conception of the nation-state than found in early Weberianism and increased awareness of international and 'world' systems.

The chapters outlining the new political sociology begin with an historical account of the development of the modern state (Chapter 2) and the major dilemmas raised by the emergence of a liberal constitutional state. A number of particular issues for state-society relationships are identified. First, the emergence of a centralised structure of institutional authority entailing relations of command and obedience ('public'), distinct from the voluntary established associations of society in which relations are typically based on affinities and ideas. To what extent does the modern state become distinct and separated from society, in which its impersonal rules attain a certain degree of freedom from the constellations of social interests? A related issue is the relative power of the public and the private, and especially state and economy. Although the centralised state with its standing armies and large treasuries casts an increasingly large shadow from the sixteenth century onwards the development of capitalism provides a strength and influence to the private sphere that, for some, enables it not only to match rulers but 


\section{xiv Introduction}

to dominate them. Second, the state that emerged in the nineteenth century came to be understood also as founded on consent, in that the state's power must be legitimated and turned into authority. Modern states come to be regarded as 'built' or 'made' purposefully and operate with reference to some idea of popular will or goal to which it is instrumental. Thus the claim to supreme authority is no longer based upon the hereditary rank of a monarchical lineage but lies in the relationship between the rulers and the ruled. The key notion is that legitimate authority is based upon the consent of the ruled, although this raises the further question of how extensive and on what basis should be this consent. The issue of who 'belongs' to the political community in turn leads to a widening social basis for the state through an extension of civic, political and social rights.

In Chapter 3 the relationship of the individual to the state (sovereignty) is distinguished from the related problem of the relationship of state to private power. At the moral heart of a number of state-society questions is the issue of whether the state is regarded as the guarantor of liberty and equality, or as a threat. Socialists come to see the state as the purposeful builder of a more just and equal society, while liberals find its paternal and collectivist influence and the search for impersonal equality inherently dangerous. In this view individual liberty and social dynamism derive from the unfettered institutions of private property and the family. However, as we shall see, even Marxism has been characterised by an ambivalence towards the state. Is it an oppressive, authoritarian and essentially bourgeois creation that has to be smashed in the pursuit of a freer society, or an essential tool in the building of a socialist society free from material want and able to defend itself from hostile capitalist states? Chapter 3 examines the different interpretations of state-society relationships and considers the external face of the nation-state through notions of imperialism and state-state exploitation and rivalry.

In Chapter 4 we return to a more historical and empirically grounded analysis of the modern state, exploring particularly the development of more collectivist forms of state-economy organisation. Although the historical connection between capitalism and liberal democracy is less pronounced than is often acknowledged (as is testified by the cases of Germany and Japan), left and right traditionally connect the necessity of the former for the development of the latter. That is, while Marxists regard the 
liberal constitutional state as predicated upon the economic requirements of the competitive phase of capitalism (and as a political rebuttal to feudalism), market society theorists see capitalism and the liberal state as mutual guarantors of individual freedoms. However, the liberal state is not necessarily a liberal democratic state, and the development of democracy is regarded by some liberals as undermining liberty through the development of collectivism. State-society relationships in the twentieth century became increasingly characterised by a concertation between organised labour, business and the state, and modern societies, whatever their political coloration apparently converge around a more state-directed, organised form of socio-economic arrangement. In the West the emerging dilemmas for the state presented by the development of electoral democracy and organised labour are first, how does the state balance the often contradictory requirements for popular support and the need for capital accumulation, and second, does this require the incorporation or the submission of labour? In the East, the dilemmas for state socialism are rather different. One reflects the perpetual socialist ambivalence to the state as an organisational form - should it be 'smashed' as an inevitable instrument of bourgeois rule or used to ensure socialist advance? In the USSR the chaos of the immediate post-revolutionary period was in part occasioned by the Leninist embrace of the former interpretation, and was replaced by the view of the state as a guarantor of the building and maintenance of 'socialism in one country'. However, the drive to state-directed industrialisation raised the additional problem of the extent to which incentive and differential rewards, apparently necessary for material advance and military and economic defence, were compatible with socialism.

In Chapter 5 we examine more specifically the issue of corporatism and the apparent displacement of parliamentarism and pluralism by a concerted form of political decision making between the organised representatives of capital, labour and the state. In part corporatist theory may be seen as a response to the benign and 'state-free' view of interest groups found in orthodox political sociology in the 1950s and 1960s. The sociology of democracy conceived interest groups as voluntary associations of like-minded citizens who would coalesce around a particular issue, but which would generally not persist. The state was regarded as either a form 
of interest group, like any other, or as a rather passive switchboard between contending private interests. Effectively the state dissolved into society. Corporatism, however, reflects the crises and recessions of the late 1960s and subsequent years in which the overwhelming and undisciplined claims of interest groups are seen as a contributory cause. Rather, new forms of authoritative state-society intermediation are required to re-impose social order, limit popular expectations and safeguard the means for economic accumulation and competitiveness. It is a strategy that risks the extension of part of state authority to the leaders of major economic associations in exchange for controlling members and eliciting support for negotiated agreements. A feature of corporatism is that the state-society distinction (public/private) becomes blurred as representative and decisional functions are combined in a range of quasi-official, non-elected administrative bodies.

In Chapter 5 we note also that, in common with pluralism, corporatism is inimical to the notion of a centralised state. Rather state authority is partially 'franchised' to powerful economic groups, whose membership is structurally rather than voluntarily generated, and the state seeks to limit the extent of its involvement in the economy for fear of damaging the means of production and accumulation. Consequently corporatism may be regarded as inherently unstable, open both to capitalist disaffection with state interference and accommodation to labour, as well as subject to trade union (rank-and-file) hostility at wage and other controls. However, the question of who benefits from corporatist arrangements is not without dispute. Although Marxists and others regard them as a means to control labour in the interests of capitalist accumulation, the persistent disaffection with corporatism displayed by both capital and 'New Right' governments suggests that the benefits to capital may be more than outweighed by the concessions to labour.

In Chapter 6 we return more specifically to a major model within orthodox political sociology - its behavioural interpretation of power. We examine the extent to which it is useful to consider policy outcomes as the consequences of choice(s) made by autonomous individuals in conflict or co-operation with others. Particularly we consider more recent approaches to power that claim that the positivistic, behavioural and conflictful conceptions of power ignored the role of ideology in human affairs and that the 
result of such an exercise of power is not necessarily conflict but its absence, not action but inaction. It may be best, therefore, to assess the benefits and costs of power independently of the desires and preferences of the individuals concerned, and the extent to which such gains or losses are cumulative or patterned.

Most of the empirical work that has underpinned discussions of power is derived from analyses of power relations in American local communities. Until recently very few local power studies had been carried out in Britain, partly because of the view that, in contrast to the United States, local government in Britain is held to be both the formal and real source of power in local communities. In Chapter 7 therefore, we examine recent interpretations of the 'local state' found in the new urban political sociology. Continuing a number of themes raised in Chapter 5, we examine claims that the local state is specifically concerned with the politics of collective consumption (housing, transport) rather than production. The assumption is that we should move away from notions of a monolithic state to one which recognises different levels and functions. Dual state theories, for example, typically distinguish between the central state, which is concerned with production and is characterised by corporatist forms of decision making, and the local state, which is concerned with consumption issues and is characterised by a more open and competitive form of decision making.

Dual state theories make more problematical the answers to question of control and external influences over urban governments. The relative openness of local political processes and the functional specificity of local government in consumption allows for both left or right, capitalist or socialist, control. The local state cannot be regarded as either a simple reflection of the central state, nor as inevitably a means for advancing capitalist interests. In recent years in Britain at least, it would have been extremely difficult to regard metropolitan authorities such as Liverpool or the Greater London Council as simply agents of capital. However, there is an ambivalence on both left and right to local government, and interpretations of urban political processes (do they benefit capitalist or non-capitalist interests?) have shown a tendency to vary according to particular political circumstances.

Finally, in Chapter 8 we seek to consider the international context for the state and redress the emphasis generally given to 'internalist' accounts of the nation-state. The distinction between 
the internal and external determinants of state action is raised and the chapter explores the theoretical assumptions behind the earlier accounts of modernisation and political development found in the sociology of democracy. In these earlier accounts the state is regarded as the major agent of modernisation, seeking initially to remove the obstacles to economic transformation as the basis for social and political reforms. However, the emphasis is still primarily internal and generally ignores the past history of relations between third and first worlds.

In the 1970s, however, political sociology has witnessed a paradigm shift in which greater emphasis is given to external factors, such as imperialism and colonialism, and in which the 'modern/traditional' dichotomy of modernisation theory is rejected. Rather, it is argued that the spread of modern institutions to the third world will further underdevelop, not modernise, them and sustain the creation of metropolis/satellite relations in the world economy. Moreover, local bourgeoisies may use the state to further a policy of underdevelopment, indicating that independence from colonial domination only changes the mode of domination. Certainly there is little to support Lenin's view in believing that direct territorial control (colonialisation) is a permanent necessity. We must also beware the danger of assuming that underdevelopment is a permanent condition for all so-called third world societies, as some countries such as Singapore and Korea have experienced considerable development. Similarly, relations between states and transnational corporations are complex and vary according to period and circumstance. States competitively respond to transnational corporations and seek to protect their own transnationals. In the third world a process of mediation takes place between state and corporations, and phases occur when corporations are strictly controlled, often by authoritarian regimes.

In conclusion the portrayal of political sociology that results in these chapters is different and less behavioural than it would have been in such a book written 15-20 years ago. There is a quite explicit concern with the state and, in concluding chapters, with approaches to state-society intermediation. There is no apology for devoting a chapter to corporatism, despite the dismissive claims of some, for it has led to a body of literature that has given much needed focus and discipline to the study of state--organisation relations, and generally more than found in some abstract accounts of the state. Similarly, 
the final two chapters seek to correct the imbalance in accounts of the state towards internal and central-level processes by returning to Marxian and Weberian state theories as applied to the local and international levels.

The picture of political sociology that emerges reflects the movement towards more radical and collective accounts of politics in modern society. However, the book emphasises the necessity in contemporary political sociology not to neglect the important contributions of the earlier orthodoxies, for to do so leads to a generally fruitless pursuit down theoretically false trails and ahistorical blind alleys. 